\title{
Breast Cancer Patients Survival and Associated Factors: Reported Outcomes from the Southern Cancer Registry in Portugal
}

\author{
Sobrevivência de Cancro da Mama e Factores Associados: Resultados do \\ Registo Oncológico Regional Sul
}

Maria do Rosário ANDRÉ ${ }^{1}$, Sandra AMARAL ${ }^{1}$, Alexandra MAYER ${ }^{2}$, Ana MIRANDA ${ }^{2}$, ROR-SUL Working Group ${ }^{2}$

Acta Med Port 2014 May-Jun;27(3):325-330

\section{ABSTRACT}

Objectives: Although the breast cancer incidence in Portugal is lower than the European average, it is the most frequent cancer in women. Overall, mortality rates are heterogeneous throughout Portugal. Implicated factors may include demographic and socioeconomic aspects, tumor biological characteristics, and access to medical care. The aim of this study is to detect survival differences in female breast cancer and identify the main associated factors.

Material and Methods: We have conducted a population-based, retrospective cohort study with follow-up. Incident breast cancer cases diagnosed in 2005 of residents in the southern region of Portugal were included. Data was collected from the Southern Portugal Cancer Registry (ROR-Sul) database and completed with clinical chart information.

Results: A total of 1354 patients were included in this study. Observed geographical variations were as follows: for age distribution, with an aging population in Alentejo; for tumor sub-types, there was a higher incidence of HER2-positive tumors in the Algarve and a higher incidence of HER2-negative tumors in Região Autónoma da Madeira. Reported estimated 5-year overall survival was $80 \%$, with significant association with tumor stage, hormone receptor and HER2 status. No survival differences were identified among women from distinct geographical regions.

Discussion: Although we found differences in age and tumor sub-type distribution between geographical regions, our study does not support the existence of discrepancies in breast cancer survival between these regions. Tumor biological characteristics seem to be the main associated factor with breast cancer survival in our population.

Conclusions: Our study confirms the association between patient survival and tumor stage, hormone receptor and HER2 status. However, no differences in patient survival were observed among different regions of residence.

Keywords: Breast Neoplasms; Neoplasm Staging; Survival Analysis; Portugal.

\section{RESUMO}

Objectivos: A incidência do cancro da mama em Portugal é inferior à média europeia, sendo, ainda assim, a neoplasia mais frequente na mulher. As taxas de mortalidade por cancro de mama apresentam uma distribuição heterogénea nas diferentes regiões de Portugal. São múltiplos os factores que podem influenciar esta distribuição, incluindo aspectos demográficos e socioeconómicos, características biológicas tumorais, e o acesso aos cuidados de saúde. O objectivo deste estudo é detectar diferenças na sobrevivência do cancro de mama feminino e os principais factores associados.

Material e Métodos: Estudo de coorte, de base populacional e orientação retrospectiva, com follow-up. Foram incluídos casos de cancro de mama diagnosticados em 2005 e residentes na região sul de Portugal, tendo os dados sido recolhidos a partir da base de dados do Registo Oncológico Regional Sul (ROR-Sul) e complementados com dados dos processos clínicos.

Resultados: Foram incluídos neste estudo 1354 doentes. Observaram-se as seguintes variações geográficas: na distribuição etária, com uma população envelhecida no Alentejo; na distribuição de sub-tipos tumorais, com uma maior incidência de tumores HER2positivo no Algarve e maior incidência de tumores HER2-negativo na Região Autónoma da Madeira. A sobrevivência global estimada aos 5 anos foi de $80 \%$, com uma associação significativa com o estadio, receptores hormonais e status HER2. Não foram identificadas diferenças na sobrevivência entre mulheres residentes em regiões geográficas distintas.

Discussão: Apesar das diferenças observadas na distribuição etária e de sub-tipos tumorais entre regiões geográficas, os nossos resultados não suportam a existência de discrepâncias na sobrevivência do cancro de mama entre estas regiões. As características biológicas tumorais parecem ser os principais factores associados à sobrevivência do cancro de mama feminino na nossa população. Conclusões: O nosso estudo confirma a associação entre a sobrevivência e o estadio, receptores hormonais e status HER2. No entanto, não foram observadas diferenças na sobrevivência entre diferentes regiões geográficas de residência.

Palavras-chave: Neoplasias da Mama; Estadiamento de Neoplasias; Análise de Sobrevida; Portugal.

\section{INTRODUCTION}

Breast cancer is the second most common cancer worldwide and the most common cancer in women in developed countries. Worldwide, the estimated incidence of 1.4 million cases and 458000 deaths per year ${ }^{1}$ correspond to $23 \%$ of total new cancer cases and $14 \%$ of total cancer deaths, respectively. ${ }^{2}$ In recent years, the breast cancer incidence rates have been increasing throughout the world. ${ }^{3}$ Age-adjusted incidence rates over three decades show an increase of $30-40 \%$ from the 1970 s to the 1990 s in most countries, notably most affecting women aged > 50 years. ${ }^{4}$ In contrast, mortality rates have decreased with an annual decline of $2.3 \%$ in age-adjusted breast cancer-

1. Department of Medical Oncology. Instituto Português de Oncologia de Lisboa Francisco Gentil. Lisbon. Portugal.

2. Southern Portugal Cancer Registry (ROR-Sul). Instituto Português de Oncologia de Lisboa Francisco Gentil. Lisbon. Portugal.

Recebido: 26 de Agosto de 2013 - Aceite: 11 de Novembro de 2013 | Copyright @ Ordem dos Médicos 2014 
related mortality from $1990-2002$ in the USA. ${ }^{5}$ In Europe, similar trends were observed in breast cancer mortality rates, with reductions of $15 \%$ between 1980 and $2000,{ }^{6}$ and $6.9 \%$ between 2002 and 2007. However, improvements in survival have not been homogeneous, as suggested by epidemiologic studies among women with breast cancer. Race/ethnic disparities persist in cancer incidence and survival. ${ }^{8-11}$ In addition, women with lower socioeconomic status have a higher risk of being diagnosed with advanced disease, and of receiving inadequate treatment, with consequent lower survival rates. ${ }^{12}$ In addition to demographic and socioeconomic factors, it is well established that tumor biological characteristics influence prognosis and survival. Patients with histological Grade 3 tumors have poorer overall survival when compared with patients with Grade 1 or 2 tumors. ${ }^{13}$ Furthermore, women with estrogen receptor (ER)-positive and/or progesterone receptor (PR)-positive tumors have a better prognosis than those with hormone receptor-negative tumors. ${ }^{14}$ In Portugal, breast cancer ranks first among cancers affecting women, ${ }^{15}$ with an agestandardized incidence rate of $60.0 / 100000$ females. ${ }^{1}$ Breast cancer mortality rates have also declined in the Portuguese population in the last decade with an estimated annual percent change of $-2 \%$ per year, with the largest declines observed in the regions that had higher mortality rates at the beginning of the period ${ }^{16}$. Overall, mortality rates seem to differ between Portuguese geographical regions, with a mortality rate of 9.5/1 000 inhabitants in Lisboa e Vale do Tejo, 14.4/1 000 in Alentejo, 11.6/1 000 in Algarve and 11.0/1 000 in Região Autónoma da Madeira. ${ }^{17}$ Hence, the scope of the present work relies on acquiring a deeper understanding of survival patterns for breast cancer patients in the Portuguese population. Specifically, we report the breast cancer profile - survival differences and associated factors - among women living in the southern region of Portugal. The major goal of the authors is to provide updated information to support national actions towards the reduction or elimination of disparities among Portuguese women with breast cancer.

\section{MATERIAL AND METHODS Study Design}

We have conducted a population-based retrospective study of female breast cancer cases from the Southern Portugal Cancer Registry (ROR-Sul). ROR-Sul is a population-based cancer registry established in 1988, which includes the south region of Portugal. This region covers a territory of $39500 \mathrm{~km}^{2}$ and encompasses a population of almost 4.5 million inhabitants. ${ }^{18}$ It includes the regions of Lisboa e Vale do Tejo (Lisboa, Santarém and Setúbal districts), Alentejo (Portalegre, Évora and Beja districts), Algarve (Faro district) and Região Autónoma da Madeira. Região Autónoma da Madeira is a Portuguese archipelago with political and administrative autonomy, localized in the North Atlantic Ocean, and composed of two inhabited islands (Madeira and Porto Santo Islands) and two groups of uninhabited islands (Desertas and Savage Islands).
This study was approved by the scientific and ethical Committee of the Portuguese Institute of Oncology-Lisbon. Confidentiality was maintained under correspondent procedures established by Portuguese Law. According to current legislation, the file containing the database record is registered in the National Commission for Data Protection, as of December 1997 (No. 1973500003).

\section{Selection of patients}

Patients included in this study had confirmed female primary breast cancer diagnosed between January 1, 2005 and December 31, 2005, and were residents in the south region of Portugal at the time of diagnosis.

\section{Pathologic Diagnostic Criteria}

Topography (primary site), histological classification and behavior were based on the ICD-O, $3^{\text {rd }}$ revision..$^{19}$ Staging of breast cancer was classified according to the American Joint Committee on Cancer Criteria (AJCC), $6^{\text {th }}$ Edition. ${ }^{20}$ Data was extracted from ROR-Sul database and supplemented with medical information from the clinical charts as needed. Collected variables included demographic characteristics (birth date, age at diagnosis, place of residence), clinical characterization (date of first medical consultation, date of diagnosis, topography, histology, tumor histological grade, ER and PR status, human epidermal growth factor receptor 2 (HER2) expression, stage), treatment options (surgery, chemotherapy, radiotherapy and hormone therapy), disease status (if death, date of death; if relapse, date of relapse). Cut-off date was December 31, 2010.

\section{Data analysis}

Frequencies were calculated for variables related to demographic, clinical and pathologic characteristics to determine their overall distribution, among stages and among geographical regions. Quantitative variables were calculated by the mean or median depending on data distribution. The differences in variable distribution between geographical regions were examined using Chisquare (qualitative variables) test and ANOVA (quantitative variables) to obtain $p$-values. Data was analyzed using Microsoft Excel 2007 and Stata/SE 12.0 for Windows, USA. Statistical significance was assessed by two-tailed tests with an alpha level of 0.05 . Survival was calculated by the Kaplan-Meyer method and compared using Log-Rank test.

\section{RESULTS}

A total of 2821 breast cancer cases diagnosed throughout 2005 were registered in ROR-Sul database. Of these, 2725 cases were effectively resident in the Southern Portugal territory at the time of diagnosis (2 150 from Lisboa e Vale do Tejo (LVT), 277 from Alentejo, 193 from Algarve and 105 from Região Autónoma da Madeira (RAM)). Because the vast majority of cases were in the LVT region $(79 \%)$, only $55 \%$ of these were randomly selected to be included in the study. After randomization we have confirmed that the remaining $45 \%$ of the population had the 
same characteristics as the included ones. All 575 cases from other regions were included. Total number of cases reviewed for the present study was 1753 (corresponding to 2104 clinical charts from different Portuguese health institutions). Following appropriate revision, 399 cases were excluded from the final analysis due to inconsistencies on inclusion criteria (e.g. date of diagnosis was different from 2005, histopathological reports did not corroborate breast invasive disease). Hence, final analysis included 1354 cases.

\section{Patient's characteristics}

A total of 1354 patients were included from 27 Portuguese health institutions. Patient characteristics are presented in Table 1. Evaluated cases were distributed as follows: 905 patients from LVT, 186 patients from Alentejo, 166 from Algarve and 97 patients from RAM. The mean age at diagnosis was 61 years (with a standard deviation of 14 years, a minimum of 22 and a maximum of 97 years) and $50 \%$ of patients were diagnosed between 40 and 65 years of age. We observed geographical variations in age distribution with an aging population in Alentejo (> 50\% of patients older than 65-years old). The most frequent

Table 1 - Clinical and Demographic Characteristics

\begin{tabular}{|c|c|c|c|c|c|}
\hline Characteristic & LVT & Alentejo & Algarve & RAM & $p$-value \\
\hline No. of patients (\%) & $905(67)$ & $186(14)$ & $166(12)$ & $97(7)$ & \\
\hline $\begin{array}{l}\text { Age Distribution, } n(\%) \\
<40 \\
\quad 40-65 \\
>65\end{array}$ & $\begin{array}{r}68(8) \\
456(50) \\
381(42)\end{array}$ & $\begin{array}{r}16(9) \\
67(36) \\
103(55)\end{array}$ & $\begin{array}{r}11(7) \\
96(58) \\
59(35)\end{array}$ & $\begin{array}{r}4(4) \\
53(55) \\
40(41)\end{array}$ & 0.002 \\
\hline $\begin{array}{l}\text { Morphology, } n(\%) \\
\text { Invasive Ductal Carcinoma } \\
\text { Invasive Lobular Carcinoma } \\
\text { Lobular and Ductal Carcinoma } \\
\text { Mucinous Carcinoma } \\
\text { Inflammatory Carcinoma } \\
\text { Others }\end{array}$ & $\begin{array}{r}770(85) \\
38(4) \\
10(1) \\
13(1) \\
1(0) \\
73(8)\end{array}$ & $\begin{array}{r}142(76) \\
6(3) \\
4(2) \\
4(2) \\
3(2) \\
27(15)\end{array}$ & $\begin{array}{r}129(78) \\
14(8) \\
2(1) \\
2(1) \\
0(0) \\
19(12)\end{array}$ & $\begin{array}{r}80(82) \\
5(6) \\
2(2) \\
1(1) \\
1(1) \\
8(8)\end{array}$ & 0.012 \\
\hline $\begin{array}{l}\text { ER, } n(\%) \\
\text { Negative } \\
\text { Positive }\end{array}$ & $\begin{array}{l}165(21) \\
615(79)\end{array}$ & $\begin{array}{r}36(23) \\
117(75)\end{array}$ & $\begin{array}{r}38(25) \\
113(73)\end{array}$ & $\begin{array}{l}21(24) \\
68(76)\end{array}$ & 0.677 \\
\hline $\begin{array}{l}\text { PR, } n(\%) \\
\text { Negative } \\
\text { Positive }\end{array}$ & $\begin{array}{l}230(29) \\
384(49)\end{array}$ & $\begin{array}{l}51(33) \\
93(60)\end{array}$ & $\begin{array}{l}58(37) \\
85(55)\end{array}$ & $\begin{array}{l}32(36) \\
56(63)\end{array}$ & 0.829 \\
\hline $\begin{array}{l}\text { HER2, } n(\%) \\
\text { Negative } \\
\text { Positive }\end{array}$ & $\begin{array}{l}534(68) \\
150(19)\end{array}$ & $\begin{array}{r}102(66) \\
31(20)\end{array}$ & $\begin{array}{l}87(56) \\
44(28)\end{array}$ & $\begin{array}{r}73(82) \\
7(8)\end{array}$ & 0.000 \\
\hline $\begin{array}{l}\text { Tumor biologic variants, } n(\%) \\
\text { HR+/HER2+ } \\
\text { HR+/HER2- } \\
\text { HR-/HER2+ } \\
\text { HR-/HER2- }\end{array}$ & $\begin{array}{r}90(11) \\
355(45) \\
44(6) \\
64(8)\end{array}$ & $\begin{array}{r}18(12) \\
88(57) \\
11(7) \\
9(6)\end{array}$ & $\begin{array}{r}33(21) \\
67(43) \\
8(5) \\
18(12)\end{array}$ & $\begin{array}{r}5(6) \\
56(63) \\
2(2) \\
16(18)\end{array}$ & 0.001 \\
\hline $\begin{array}{l}\text { Stage, } n(\%) \\
\text { I } \\
\text { II } \\
\text { III } \\
\text { IV }\end{array}$ & $\begin{array}{r}292(36) \\
327(40) \\
141(17) \\
53(7)\end{array}$ & $\begin{array}{r}65(40) \\
60(36) \\
28(17) \\
11(7)\end{array}$ & $\begin{array}{r}58(37) \\
56(35) \\
31(20) \\
13(8)\end{array}$ & $\begin{array}{r}24(26) \\
38(40) \\
28(30) \\
4(4)\end{array}$ & 0.147 \\
\hline
\end{tabular}


morphology was Invasive Ductal Carcinoma accounting for $82.8 \%$ of all cases followed by Invasive Lobular Carcinoma (4.6\%). As expected, Inflammatory Carcinoma represented only $0.4 \%$ of all cases. Staging distribution shows that $32 \%$ of patients presented with Stage I disease, $36 \%$ with Stage II, $17 \%$ with Stage III and $6 \%$ presented metastatic disease ab initio. Analyzing stage distribution by geographical area showed fewer Stage I patients $(26 \%)$ in RAM. For the 1 181 patients with hormone receptor status information, 49\% (584) were both ER- and PR-positive, 15\% (172) were ERpositive and PR-negative, 3\% (34) were ER-negative and PR-positive, and $17 \%$ (199) were ER- and PR-negative. Mean age at diagnosis was 61 years for ER-positive and PR-positive, 61 years for ER-positive and PR-negative, 57 years for ER-negative and PR-positive, and 59 years for ER-negative and PR-negative. This was not significantly different $(p=0.082)$ by one-way analysis of variance for joint ER and PR profiles. HER2 status information was available for 1028 cases $(76 \%)$, with the majority of them (796 cases, 77\%) being HER2-negative. The remaining 23\% (232 cases) had HER2-positive disease. Mean age at diagnosis was 61 for HER2-negative and 57 for HER2positive disease. The analysis for joint ER/PR/HER2 profiles revealed a high proportion (48\%) of ER-positive/PR-positive/ HER2-negative tumors. Twelve percent of tumors were triple-positive (ER-positive/PR-positive/HER2-positive), 6\% presented as ER-negative/PR-negative/HER2-positive and 9\% were triple negative (ER-negative/PR-negative/HER2negative). We observed some significant differences in the geographical distribution of tumor profiles, with a higher incidence of triple-negative tumors in RAM and a higher incidence of triple-positive tumors in the Algarve compared with other regions.

\section{Treatment patterns}

Eighty-eight percent of patients (1195 cases) were submitted to a surgical procedure, with conservative surgery being performed in $46 \%$ and radical mastectomy in $42 \%$ of cases. Chemotherapy was administered to $53 \%$ of patients, radiotherapy was performed in $61 \%$ and hormone therapy was given to $64 \%$ of patients. Looking at treatment

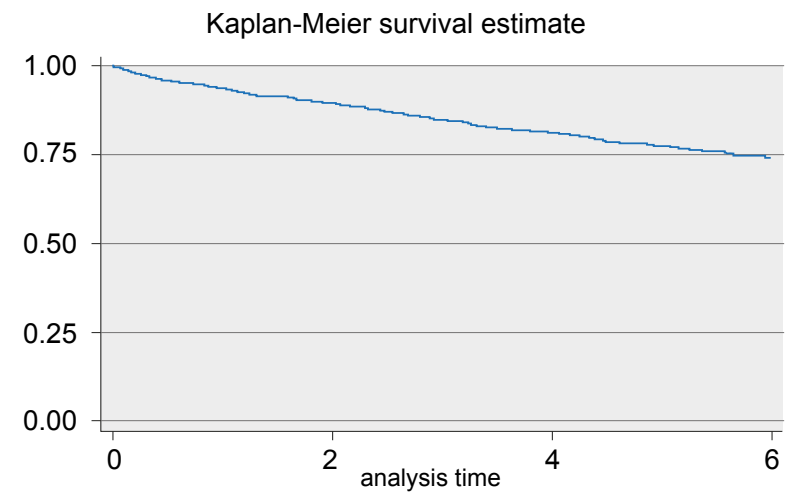

Figure 1 - Overall Survival, Kaplan-Meier options by tumor stage, there was an association between stage and surgery, with less surgery being performed in Stage III (18\%) and IV (2\%), and an association between chemotherapy and tumor stage, with more chemotherapy being given to Stage II patients (49\%). Patterns of treatment were not different between geographical regions. Regarding the time elapsed between diagnosis and treatment we registered a similar interval of 2.3 months in all geographical regions.

\section{Survival}

We observed a 5 -year overall survival of $80 \%$ for the population in the present study (Fig. 1). There is an association between survival and staging $(p=0.00)$, with a 5 -year survival of $92 \%$ for patients presenting with Stage I disease, $86 \%$ for Stage II, $60 \%$ for Stage III and a survival of $20 \%$ for Stage IV (Fig. 2). Kaplan-Meier plots for overall survival by hormone receptor expression revealed an improved survival in the ER-positive group compared with the ER-negative group, and in the PR-positive group compared with the PR-negative group. When analyzing survival accordingly with tumor HR/HER2-triple phenotypes $(p=0.00)$, we found a progressive decreasing survival from the triple positive (ER-positive/PR-positive/HER2-positive) tumor sub-type to the ER-positive/PR-positive/HER2negative, ER-negative/PR-negative/HER2-positive and ERnegative/PR-negative/HER2-negative (Fig. 3). There were no survival differences for the studied geographical regions $(p=0.7637)$ (Fig. 4).

\section{DISCUSSION}

This study reports a unique analysis of possible geographical variations in breast cancer epidemiology and management across South Portugal. Hence, the disclosure of this information will support further understanding of the magnitude of unmet medical needs, in parallel with the knowledge of high risk regions for breast cancer in the southern territory of Portugal.

In this retrospective study, survival was substantially inferior in patients with advanced disease, as well as in patients with triple-negative tumors. Geographical region of

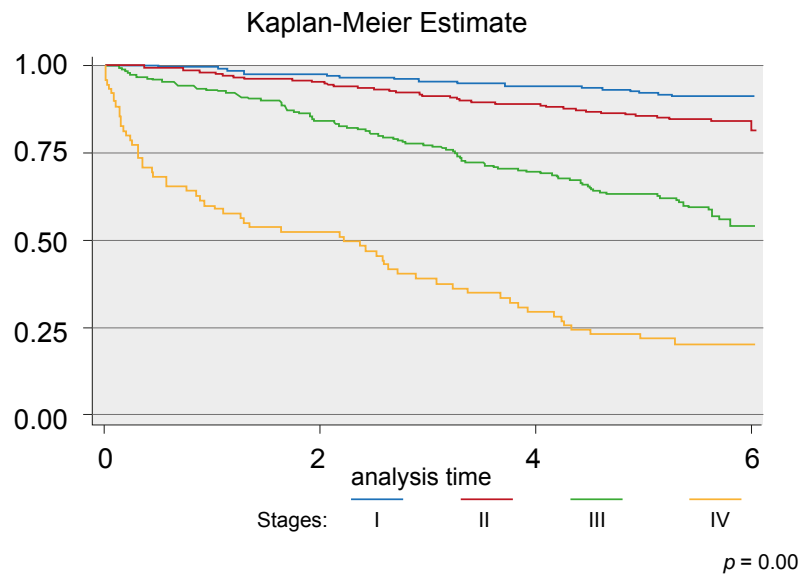

Figure 2 - Survival by Stage, Kaplan-Meier 


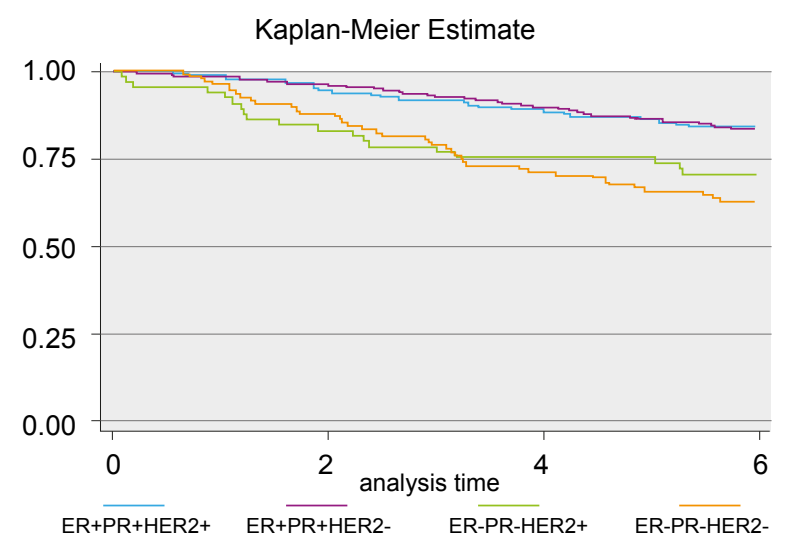

$p=0.00$

Figure 3 - Survival by Tumor HR/HER2 phenotypes, Kaplan-Meier

residence did not substantially affect survival.

The observed differences in age distribution by geographical regions, with an aged population in Alentejo, are in accordance with our previous knowledge of the Portuguese population distribution between regions, with more elderly people in rural areas. In our study, the incidence of early stage disease was lower in RAM. The difference between regions may be due to differences in access to health care. Also it has been suggested by some studies ${ }^{11,12}$ that women who have higher education are more likely to present with early-stage breast cancer, and this can also be responsible for these differences with less educated women in the more rural areas. ER-positive breast cancers are known to correlate with a better outcome than those that are ER-negative, as they respond better to hormone therapy. In our study, we did not find differences in the incidence of HR tumor expression patterns among regions. On the contrary, we noticed differences when considering HER2 status, with a high incidence of HER2-negative tumors in RAM, and a high number of HER2-positive tumors in the Algarve. Further studies will need to be completed to clarify whether these differences represent a truly geographical variation of biologically distinct diseases, or solely reflect differences in the assay methods used to evaluate HER2 status. Survival analysis by stage confirmed a higher survival at 5 years in patients with localized disease and lower survival in patients with advanced disease. In addition, we confirmed an influence of tumor biological characteristics for survival, showing a better outcome for the triple-positive HR-positive/ HER2-positive patients group and worse outcome for the triple-negative group. Finally, there were no evident differences in survival between Portuguese geographical regions in our study.

Our results need to be considered in light of the study strengths and weaknesses. The main strength of this study is the number of patients included. Nevertheless, the distribution by geographical region is not equitable, and number of patients is relatively small in some of the sub-groups (e.g. RAM). We also recognize other significant limitations. The study was retrospective in nature, and data quality was dependent on the thoroughness of data

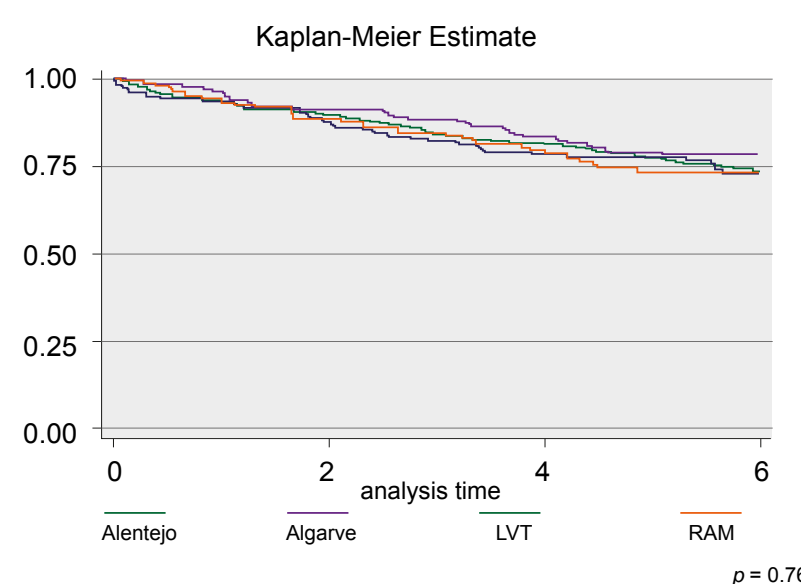

Figure 4 - Survival by Geographical Region, Kaplan-Meier

collection and medical records. Also, we acknowledge the possible effect of measurable and no-measurable confounders in our results.

In conclusion, our study confirms the association between patient survival and tumor stage, hormone receptor and HER2 status, and raises important questions, namely regarding the geographical variation of tumor subtypes and the apparent inexistence of survival differences in breast cancer patients across the various geographical studied regions.

\section{ACKNOWLEDGEMENTS}

\section{The ROR-Sul Working Group consists of:}

Ana Alcazar (Hospital de Reynaldo dos Santos), Ana Miranda (Instituto Português de Oncologia de Lisboa Francisco Gentil), Ana Palha (Centro Hospitalar de Lisboa Norte - Hospital de Santa Maria), Ana Paula Horta (Hospital Militar Principal), Artur Lopes (Unidade Local de Saúde do Norte Alentejano - Hospital de Portalegre), Carlos Aldeia (Hospital do Litoral Alentejano), Carlos Boto (Centro Hospitalar Médio Tejo - Unidade de Tomar), Cláudia Fraga (Centro Hospitalar do Funchal), Carvalheira Santos (Centro Hospitalar de Lisboa Norte - Hospital Pulido Valente), Daniela Cunha (Hospital Curry Cabral), Fernanda Marcos (Centro Hospitalar de Lisboa Central), Gabriela Valadas (Centro Hospitalar do barlavento Algarvio), Helena Oliveira (Centro Hospitalar de Cascais), Irene Furtado (Hospital Distrital de Faro), Isabel Carvalho (Centro Hospitalar de Torres Vedras), Isabel Gonçalves (Centro Hospitalar de Setúbal), Joaquim Gouveia (Hospitais CUF), Luísa Gloria (Hospital Distrital de Santarém), Maria José Brito (Hospital Garcia de Orta), Osvaldo Francês (Centro Hospitalar Médio Tejo - Unidade de Torres Novas), Rosa Madureira (Hospital Nossa Senhora do Rosário), Rui Coelho (Centro Hospitalar Médio Tejo - Unidade de Abrantes), Sância Ramos (Hospital de Egas Moniz and Hospital de Santa Cruz and Hospital São Francisco Xavier), Sérgio Barroso (Centro Hospitalar Baixo Alentejo), Sofia Loureiro Santos (Hospital Fernando Fonseca), Teresa Barreiros (Hospital do Montijo), Teresa Timóteo (Hospital Espírito Santo de Évora), Tereza Paula Gomes (Maternidade Alfredo da Costa), Victor Silva 
(Unidade Local de Saúde do Norte Alentejano - Hospital Santa Luzia de Elvas).

\section{CONFLICTS OF INTEREST}

The authors declare that they have no conflicts of interest.

\section{REFERENCES}

1. Ferlay J, Shin HR, Bray F, Forman D, Mathers C, Parkin DM. GLOBOCAN 2008 v1.2, Cancer incidence and mortality worldwide: IARC CancerBase No. 10. Lyon, France: International Agency for Research on Cancer; 2010.

2. Jemal A, Bray F, Center MM, Ferlay J, Ward E, Forman D. Global cancer statistics. CA Cancer J Clin. 2011;61:69-90.

3. Parkin DM, Fernandez LM. Use of statistics to assess the global burden of breast cancer. Breast J. 2006;12:S70-80.

4. Althuis MD, Dozier JM, Anderson WF, Devesa SS, Brinton LA. Global trends in breast cancer incidence and mortality 1973-1997. Int J Epidemiol. 2005;34:405-12.

5. Edwards BK, Brown ML, Wingo PA, Howe HL, Ward E, Ries LA, et al. Annual report to the nation on the status of cancer, 1975-2002, featuring population-based trends in cancer treatment. J Natl Cancer Inst. 2005;97:1407-27.

6. Levi F, Bosetti C, Lucchini F, Negri E, La Vecchia C. Monitoring the decrease in breast cancer mortality in Europe. Eur $\mathrm{J}$ Cancer Prev. 2005;14:497-502.

7. Bosetti C, Bertuccio P, Levi F, Chatenoud L, Negri E, La Vecchia C. The decline in breast cancer mortality in Europe: An update (to 2009). Breast. 2012;21:77-82.

8. Smigal C, Jemal A, Ward E, Cokkinides V, Smith R, Howe HL, et al. Trends in breast cancer by race and ethnicity: update 2006. CA Cancer J Clin. 2006;56:168-83.

9. Hill DA, Nibbe A, Royce ME, Wallace AM, Kang H, Wiggins $C L$, et al. Method of detection and breast cancer survival disparities in Hispanic women. Cancer Epidemiol Biomarkers Prev. 2010;19:2453-60.

10. Chu KC, Tarone RE, Brawley OW. Breast cancer trends of black women

\section{FUNDING SOURCES}

The authors thank the Portuguese Ministry of Health for funding this research. The funding source had no role in the study design, writing this paper, or the decision to submit it for publication.

compared with white women. Arch Fam Med. 1999;8:521-8.

11. Chu KC, Lamar CA, Freeman HP. Racial disparities in breast carcinoma survival rates: separating factors that affect diagnosis from factors that affect treatment. Cancer. 2003;97:2853-60.

12. Bradley CJ, Given CW, Roberts C. Race, Socioeconomic Status, and Breast Cancer Treatment and Survival. J Natl Cancer Inst. 2002;94:4906.

13. Elston CW, Ellis IO. Pathological prognostic factors in breast cancer. I. The value of histological grade in breast cancer: experience from a large study with long-term follow-up. Histopathology. 1991;19:403-10.

14. Joslyn SA. Hormone receptors in breast cancer: racial differences in distribution and survival. Breast Cancer Res Treat. 2002;73:45-59.

15. Registo Oncológico Regional Sul. Incidência, Sobrevivência e Mortalidade por Cancro na Região Sul de Portugal - ISM 2006. Lisboa: RORS; 2012.

16. Bastos $\mathrm{J}$, Barros $\mathrm{H}$, Lunet $\mathrm{N}$. Evolução da mortalidade por cancro da mama em Portugal (1955-2002). Acta Med Port. 2007;20:139-44.

17. Instituto Nacional de Estatística. Estatísticas Demográficas. Lisboa: INE; 2007. [Consulted 2013 May 13]. Available on: http://www.ine.pt.

18. Instituto Nacional de Estatística. Estimativa anual da população residente para o ano 2005, por género e grupos etários, NUTS I, II, III e Municípios (NUTS 2002). [Consulted 2013 May 13]. Available on: http:// www.ine.pt.

19. World Health Organization. International Classification of Diseases for Oncology. $3^{\text {rd }}$ ed. Geneva: WHO; 2000.

20. International Union Against Cancer. TNM Classification of Malignant Tumours. $6^{\text {th }}$ ed. Geneva: UICC; 2002. 


\section{Breast Cancer Patients Survival and Associated Factors: Reported Outcomes from the Southern Cancer Registry in Portugal

\author{
Acta Med Port 2014:27:325-330
}

Publicado pela Acta Médica Portuguesa, a Revista Científica da Ordem dos Médicos

Av. Almirante Gago Coutinho, 151

1749-084 Lisboa, Portugal.

Tel: +351 218428215

E-mail: submissao@actamedicaportuguesa.com

www.actamedicaportuguesa.com

ISSN:0870-399X | e-ISSN: 1646-0758

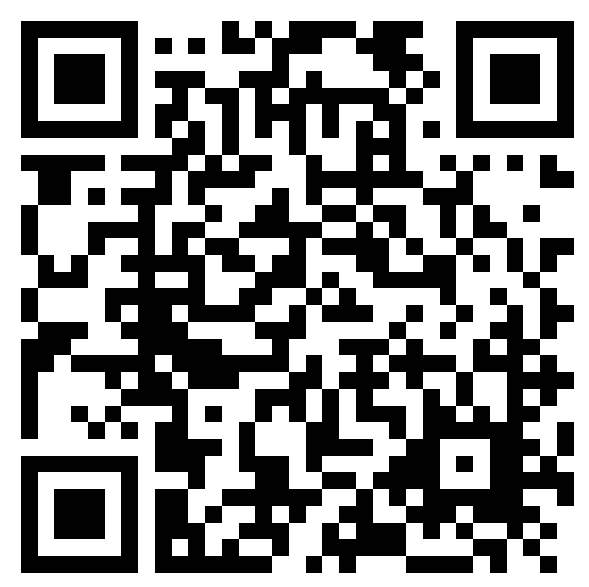

